\title{
Pengaruh Pembinaan Keagamaan Oleh Samanera Dan Atthasilani Terhadap Perilaku Keagamaan Umat Buddha Di Malang Raya
}

\author{
Kadek Yudi Murdana, Milia Panna Santi, Rakyan Paranimmita S.K \\ Sekolab Tinggi Agama Buddha Kertarajasa \\ stab.kertarajasa@gmail.com
}

\begin{abstract}
This study aimed to determine the influence of religious formation by Samanera and Atthasilani on Buddhist religious behavior in Malang Raya. The approach used in this research is quantitative research with the type of research included in the survey research. The results showed that religious guidance has a significant influence on Buddhist religious behavior in Malang Raya, can be proved from correlation value 0.724 or $72.4 \%$ and significant with 0.000 value. This shows that there is a significant influence between the variables of religious development on Buddhist religious behavior in Malang Raya.
\end{abstract}

Keywords: construction of religious, samanera, atthasilani, religious behavior

\begin{abstract}
Abstrak
Penelitian ini bertujuan untuk mengetabui pengarub pembinaan keagamaan oleb Samanera dan Atthasilani terhadap perilaku keagamaan umat Buddha di Malang Raya. Pendekatan yang digunakan dalam penelitian ini adalab penelitian kuantitatif dengan jenis penelitian termasuk ke dalam peneitian survei. Hasil penelitian menunjukkan babwa pembinaan keagamaan memiliki pengarub yang signifikan terhadap perilaku keagamaan umat Buddha di wilayah Malang Raya, dapat dibuktikan dari nilai korelasi 0,724 atau 72,4\% dan signifikan dengan nilai 0,000. Hal ini menunjukkan bahwa ada pengarub yang signifikan antara variabel pembinaan keagamaan terhadap perilaku keagamaan umat Buddha di wilayah Malang Raya.
\end{abstract}

Kata Kunci: pembinaan keagamaan, samanera, atthasilani, perilaku keagamaan Permalink/DOI: http://dx.doi.org/10.18326/infsl3v12i1.127-148 


\section{Pendahuluan}

Dalam sejarahnya, daerah Malang Raya memiliki hubungan yang erat dengan perkembangan agama Buddha di Indonesia. Hal ini terjadi pada masa perkembangan kerajaan Singosari (Singhasari) dimana hal tersebut didukung dengan ditemukannya berbagai peninggalan seperti candi-candi Buddhis. Berdasarkan pada hal tersebut, dapat dikatakan pula bahwa daerah Malang Raya pada masanya, pernah dihuni oleh masyarakat beragama Buddha. Oleh karena itu, tidaklah mengherankan jika pada masa sekarang masih banyak ditemukan komunitas masyarakat yang beragama Buddha tersebar di berbagai daerah sekitar Malang Raya.

Dalam wilayah Kota Malang, berdasarkan pada data statistik tahun 2010 BPS Kota Malang, di seluruh wilayah yang terdiri dari lima kecamatan, terdapat populasi umat Buddha dengan jumlah total 7.170 orang (BPS Kota Malang, 2011). Sedangkan dari wilayah Kabupaten Malang, jumlah perkembangan pemeluk Agama di tahun 2014 dan 2015 berdasarkan data BPS Kabupaten Malang adalah sejumlah 5.570 orang di tahun 2014 dan mengalami sedikit penurunan menjadi total 5.479 orang di tahun 2015, yang tersebar di sepuluh kecamatan, yaitu: Kecamatan Gedangan, Kecamatan Dampit, Kecamatan Tirtoyudo, Kecamatan Poncokusumo, Kecamatan Sumberpucung, Kecamatan Wonosari, Kecamatan Wagir, Kecamatan Jabung, Kecamatan Lawang, dan Kecamatan Kasembon (BPPD Kab. Malang, 2016).

Dalam perkembangannya, umat Buddha di Indonesia, khususnya di Malang Raya, tidak hanya menjadi komunitas minoritas dalam kaitannya dengan jumlah penduduk secara keseluruhan, tetapi juga terbagi menjadi beberapa sekte yang berbeda. Dengan jumlah total penganut yang tidak besar dan terbagi ke dalam beberapa sekte, maka komunitas umat Buddha dalam satu kelompok sekte yang sama akan menjadi semakin kecil.

Dengan kondisi demikian, maka pembinaan keagamaan terhadap umat Buddha menjadi kebutuhan yang sangat pokok, mengingat kondisi persebaran masyarakat Buddhis di berbagai tempat dengan jumlah yang tidak merata. Tantangan lain yang 
harus dihadapi yaitu kondisi geografis, khususnya wilayah Kabupaten Malang, dimana selain jarak yang jauh antar kecamatan yang terdapat komunitas umat Buddhanya, juga beberapa tempat memiliki kondisi geografis yang ekstrem dalam aspek lokasi dan akses jalan. Selain itu, rasio jumlah umat Buddha tidak berimbang dengan jumlah pembina umat seperti viharawan, penyuluh, pandita, ataupun guru-guru agama. Hal ini dapat dilihat dari fakta bahwa mayoritas tempat dimana terdapat komunitas umat Buddha, walaupun terdapat vihara sebagai tempat ibadah dan melakukan berbagai aktivitas keagamaan, tidak memiliki bhikkhu yang tinggal di vihara tersebut dalam jangka waktu lama yang dapat melakukan pembinaan.

Dalam aspek yang lebih positif, dengan berbagai kondisi yang kurang mendukung seperti tersebut di atas, komunitas umat Buddha masih dapat mempertahankan eksistensinya. Walaupun terdapat beberapa kasus konversi agama dari Buddhis ke Nonbuddhis hampir di berbagai daerah, seperti dalam penelitian oleh Purwoto, dkk. (2016), namun fenomena tersebut tidak terjadi dalam jumlah yang terlalu signifikan. Di samping itu, integritas para umat masih dapat terjaga, dimana hal tersebut terlihat pada waktu diselenggarakannya perayaan-perayaan yang bersifat massal, seperti perayaan Hari Trisuci Waisak, yang merupakan salah satu hari raya terbesar bagi umat Buddha, para umat dari berbagai daerah turut mengikuti perayaan tersebut yang biasanya terpusat di satu tempat atau beberapa tempat secara bersamaan ataupun bergantian.

Semakin berkembangnya jaman dan teknologi, pola pembinaan umat juga turut berkembang, dengan semakin banyaknya jumlah elemen yang turut melakukan pembinaan keagamaan ke berbagai daerah selain para bhikkhu, pandita dan penyuluh agama Buddha. Salah satu elemen tersebut adalah para samanera dan atthasilani, yang juga merupakan bagian dari viharawan. Walaupun memiliki kedudukan yang lebih rendah dari seorang bhikkhu, namun para samanera dan atthasilani juga adalah viharawan yang tinggal di vihara dan dalam masa pembelajaran untuk meninggalkan keduniawian dan melakukan latihan kemoralan yang lebih tinggi daripada umat biasa pada umumnya. Oleh karena itu, samanera dan 
atthasilani juga mendapat kedudukan dalam masyarakat sebagai pembimbing dalam aspek keagamaan.

Padepokan Dhammadipa Arama, sebuah vihara yang terdapat di Kota Batu, adalah salah satu tempat dimana terdapat samanera dan atthasilani dalam jumlah yang banyak. Program samanera dan atthasilani juga adalah salah satu program unggulan dari Sekolah Tinggi Agama Buddha (STAB) Kertarjasa yang terletak berdampingan dengan vihara tersebut. Program ini telah dimulai sejak tahun 2007 hingga sekarang, dimana beberapa alumninya telah menjadi bhikkhu dan atthasilani tetap.

Dalam kaitannya dengan pola pembinaan umat, para samanera dan atthasilani tersebut ditugaskan secara rutin untuk melakukan pembinaan umat tidak hanya di wilayah Malang Raya, namun juga meliputi seluruh wilayah di Indonesia. Pola pembinaannya sendiri diasumsikan telah berjalan dengan baik, dengan melihat fakta bahwa permintaan untuk diadakannya pembinaan yang datang dari berbagai daerah di Indonesia semakin banyak dari waktu ke waktu.

Menurut Soetopo dan Soemanto (dalam Syafaat, dkk, 2008) pembinaan menunjuk pada suatu kegiatan untuk mempertahankan ataupun meningkatkan sesuatu yang telah ada. Keagamaan menurut Anshari (1980) merupakan suatu sistem tata keyakinan atas adanya yang sesuatu yang mutlak, serta sistem norma yang mengatur hubungan manusia dengan manusia dan alam lainnya, sesuai dengan tata keimanan dan peribadatan yang dimaksud.

Berdasarkan pada beberapa pengertian di atas, dapat diketahui bahwa pembinaan keagamaan adalah suatu proses, cara, atau perbuatan membina dalam kaitannya dengan agama. Adapun proses tersebut dilakukan dengan beberapa tujuan seperti membentuk, mempertahankan atau meningkatkan. Membentuk dalam hal ini adalah ketika nilai-nilai atau norma-norma keberagamaan dalam suatu individu atau kelompok adalah dalam kondisi yang tidak atau belum tertata, sehingga diperlukan adanya pembinaan untuk membentuk suatu esensi keagamaan dalam diri individu atau kelompok tersebut. Mempertahankan suatu nilai atau norma keagamaan perlu dilakukan dalam kondisi dimana suatu tatanan individu atau kemasyarakatan telah terbentuk sesuai dengan 
nilai-nilai atau norma keagamaan yang benar. Dan peningkatan diperlukan ketika terdapat nilai atau norma tertentu yang berpotensi yang dikembangkan dan ditingkatkan ke tataran yang lebih baik.

Pembinaan keagamaan umat yang dimaksudkan di sini adalah usaha yang direncanakan secara sistematis berupa bimbingan, pemberian informasi, pengawasan dan juga pengendalian untuk peningkatan kualitas para umat Buddha, khususnya dalam hal keagamaan dalam menciptakan sikap mental dan pengembangan potensi yang positif sehingga terbentuk karakter yang positif dalam diri umat Buddha.

Pembinaan Umat Buddha tersebut dilaksanakan dalam bentuk kegiatan-kegiatanseperti tuntunan melaksanakan puja bhakti, penjelasan dan praktik metode-metode meditasi, pembinaan Sekolah Minggu bagi anak-anak Buddhis, pembabaran khobah Dhamma, hingga pada konsultasi tentang beragam pemecahan masalah dalam kehidupan sehari-hari.

Perilaku adalah segala perbuatan atau tindakan yang dilakukan oleh makhluk hidup (Notoatmodjo, 2010). Skinner, seorang ahli psikologi, merumuskan bahwa perilaku merupakan respon atau reaksi seseorang karena adanya stimulus (rangsangan dari luar). Oleh karena perilaku ini terjadi melalui proses adanya stimulus terhadap organisme, dan kemudian organisme tersebut merespon. Teori ini disebut teori "S-O-R" atau Stimulus Organisme Respons (Slavin, 2011). Menurut Pavlov, perilaku terjadi karena adanya proses yang secara berulang-ulang menghubungkan rangsangan netral sebelumnya denganrangsangan tanpa pengondisian yang berguna untuk membangkitkan tanggpana pengondisian (Slavin, 2011).

Dalam kaitannya dengan perilaku keagamaan dalam masyarakat Buddhis, Sang Buddha telah menjabarkan berbagai nilai-nilai atau norma-norma yang patut untuk dilaksanakan dalam kehidupan sehari-hari dalam membentuk suatu perilaku yang benar sehingga membawa pada pencapaian kebahagiaan dan kedamaian. Bahkan dalam tataran yang lebih tinggi, yaitu seorang raja atau pemimpin, raja atau pemimpin yang adil dan bijak, perlu untuk berpegang pada Dhamma, memuliakan Dhamma, menjunjung 
dan menghormatinya, dengan Dhamma sebagai tolok ukur, panji serta junjungannya, memberikan perlindungan, naungan, dan keselamatan yang berkaidah hukum bagi para abdinya (Bodhi, 2013).

Terdapat enam akar perselisihan yang patut dihindari serta tujuh asas stabilitas sosial yang patut dijaga. Keenam akar perselisihan tersebut yakni: sifat marah dan benci, berdiam tanpa rasa hormat dan patuh kepada Sang Guru, Dhamma serta Sangha, dan tidak menjalani latihannya; sifat menghina dan merendahkan; iri dan kikir; pembohong serta curang; memiliki kehendak jahat serta pandangan salah; dan menganut pandangannya sendiri, berpegang teguh padanya, dan sulit melepaskannya (Bodhi, 2013).

Kondisi yang paling mendukung untuk pencapaian pembebasan mutlak yang diajarkan Buddha adalah menjalani kehidupan sebagai seorang petapa (viharawan), yang telah bertekad untuk meninggalkan berbagaibentuk keduniawian dan melaksanakan praktik pengembangan batin (meditasi) untuk mengembangkan pengetahuan dan kebijaksanaan sampai pada puncaknya. Namun pada praktiknya, tidak semua orang dapat dengan mudah menjalani kehidupan sebagai seorang petapa, terutama bagi umat yang telah menjalani kehidupan sebagai perumahtangga. Oleh karena itu, Buddha juga mengajarkan Dhamma yang baik untuk dilaksanakan oleh umat Buddha yang menjadi perumahtangga. Ajaran tersebut intinya adalah untuk membentuk suatu perilaku keagamaan yang baik di antara umat awan, sehingga suatu kebahagiaan hidup akan mampu tercapai, baik dalam kehidupan sekarang maupun akan datang. Ajaran-ajaran tersebut dapat ditemukan dalam berbagai khotbah yang disampaikan, namun intisarinya dapat ditemukan dalam syair Dhammapada yang berbunyi: "Tidak melakukan berbagai bentuk kejahatan (keburukan); menambah berbagai bentuk kebajikan; memurnikan batin; inilah ajaran para Buddha". (Sarada, 1993).

Berdasarkan pada syair yang terdapat dalam kitab Dhammapada diatas, maka dapat diasumsikan bahwa seorang umat Buddha dapat dikatakan memiliki perilaku keagamaan yang baik jika dia mampu mempraktikkan ajaran yang terkandung di dalam 
syair tersebut, yaitu: 1) Melaksanakan latihan Pañcasila, Pañcasila (Lima Latihan Moral) yang terdiri dari: penghindaran pembunuhan makhluk hidup; penghindaran dari pencurian; penghindaran dari perbuatan asusila; penghindaran dari ucapan-ucapan salah; dan penghindarang dari berbagai bentuk makanan atau minuman yang memabukkan dan melemahkan kewaspadaan. (Jotalankara, 2004). 2) Berdana, Dana pemberian dalam agama Buddha dapat berupa materi atau non-materi. Dana yang mudah dan sangat dianjurkan untuk dilakukan dalam kehidupan sehari-hari yaitu berdana materi berupa empat kebutuhan pokok seorang bhikkhu, berdana bunga, air, pelita dan dupa pada altar. Berdana kebutuhan pokok seorang bhikkhu dapat dilakukan secara langsung maupun pada saat dilangsungkannya prosesi pindapatta yaitu bhikkbu berkeliling untuk menerima dana makanan dari para umat. 3) Memurnikan batin, Memurnikan batin dapat dilakukan dengan melaksanakan praktik meditasi atau pengembangan batin, yang mana hal ini dapat dilakukan baik di rumah ataupun di vihara, maupun di tempattempat retreat meditasi yang dilaksanakan secara berkala selama kurun waktu tertentu. Adapun Buddha telah mengajarkan dua metode meditasi, yaitu samatha bhavana dan vipassana bhavana.

Penelitian ini bertujuan untuk mengetahui pengaruh antara pembinaan keagamaan oleh samanera dan atthasilani terhadap perilaku keagamaan umat Buddha di Malang Raya.

\section{Metode Penelitian}

Pendekatan yang digunakan pada penelitian ini adalah penelitian kuantitatif. Jenis penelitian ini termasuk ke dalam peneitian survei. Penelitian ini adalah penelitian yang menggunakan kuesioner (angket) sebagai instrumen dan sumber data primernya (Prasetyo, 2005).

Penelitian ini dipusatkan pada enam lokasi yaitu: wilayah Desa Ampel Gading, Desa Sukorame, Desa Jatiguwi dan Desa Bara'an (Kabupaten Malang); Vihara Samaggi Viriya (Kota Malang); dan Dusun Ngandat (Kota Batu). Keenam tempat tersebut dipilih karena pada wilayah tersebut kegiatan pembinaan keagamaan 
Buddha berjalan secara aktif dan berkesinambungan, sehingga dirasa akan mampu mewakili kegiatan penyuluhan di wilayah Malang Raya secara keseluruhan.

Teknik pengambilan sampel atau teknik sampling yang digunakan adalah probability sampling, yaitu dengan simple random sampling, untuk penelitian kuantitatif, dimana dalam hal ini populasi akan dibatasi berdasarkan beberapa kriteria seperti: umat yang aktif ke vihara dan mengikuti pembinaan, serta pembatasan usia antara 13-60 tahun.

Skala pengukuran yang dipakai dalam penelitian kuantitatif adalah menggunakan Skala Likert, untuk mengetahui skala dari pembinaan keagamaan yang dilakukan dan perilaku keagamaan dalam masyarakat sebagai subjek kajian. Pengumpulan data akan dilakukan melalui observasi, penyebaran kuesioner (angket), dan dokumentasi.

Teknik analisis data dilakukan pengujian validitas dan reliabilitas terhadap instrumen penelitian. Pengujian validitas instrumen dilakukan dengan menggunakan pengujian validitas konstruksi yang menggunakan pendapat dari ahli (judgment experts). Pengujian reliabilitas instrumen dilakukan secara eksternal menggunakan teknik test-retest.

Dalam menganalisis data, peneliti menggunakan metode analisis kuantitatif untuk mengetahui pengaruh pembinaan keagamaan oleh samanera dan atthasilani terhadap perilaku keagamaan umat Buddha di Malang Raya dilakukan dengan skala Likert. Teknik analisis data dalam penelitian kuantitatif menggunakan paradigma sederhana untuk mengukur skala dari kedua variabel dan menggunakan teknik Korelasi Pearson Product Moment.

\section{Hasil Penelitian Dan Pembahasan}

Pengarub Pembinaan oleh Samanera dan Atthasilani terhadap Perilaku Keagamaan Umat Buddha di Ampelgading

Hasil uji koefisien korelasi variabel bebas atau pengaruh pembinaan terhadap variabel terikat atau perilaku keagamaan 
umat Buddha di wilayah Ampelgading menggunakan SPSS 15.0 for windows adalah sebagai berikut.

\section{Tabel 1.}

\section{Hasil Uji Koefisien Korelasi Variabel X dan Variabel Y}

\begin{tabular}{|ll|c|c|}
\multicolumn{2}{|c|}{ Correlations } \\
& & $\begin{array}{c}\text { Pembinaan } \\
(\mathrm{x})\end{array}$ & $\begin{array}{c}\text { Perilaku } \\
\text { Keagamaan } \\
(\mathrm{y})\end{array}$ \\
\hline Pembinaan $(\mathrm{x})$ & Pearson Correlation & 1 & $.631^{\star *}$ \\
& Sig. (2-tailed) & 20 & .003 \\
& $\mathrm{~N}$ & $.631^{\star *}$ & 20 \\
\hline Perilaku Keagamaan (y) & Pearson Correlation & .003 & 1 \\
& Sig. (2-tailed) & 20 & 20 \\
& $\mathrm{~N}$ & & \\
\end{tabular}

**. Correlation is significant at the 0.01 level (2-tailed).

Dari tabel di atas dapat dilihat bahwa variabel pembinaan keagamaan (X) mempunyai pengaruh positif terhadap perilaku keagamaan di wilayah Ampelgading dengan nilai 0.631 atau 63,1\% dan signifikan dengan nilai 0.003. Hal ini menunjukkan bahwa ada pengaruh yang signifikan antara variabel pembinaan keagamaan terhadap perilaku keagamaan umat Buddha di wilayah Dampit.

Selanjutnya dilakukan uji koefisien korelasi subvariabel untuk mengetahui subvariabel mana yang memberikan pengaruh terhadap perilaku keagamaan paling signifikan.

\section{Tabel 2}

\section{Rekapitulasi Hasil Analisis Korelasi Subvariabel}

\begin{tabular}{|c|c|c|c|c|}
\hline Variabel & $\mathrm{r}_{\text {hitung }}$ & $\mathrm{r}_{\text {tabel (n } 20)}$ & Sig. & Keterangan \\
\hline $\begin{array}{c}\text { Pembina Keagamaan (X1) } \\
\text { dan Perilaku Keagamaan (y) }\end{array}$ & 0,101 & 0,444 & 0,671 & Tidak Signifikan \\
\hline $\begin{array}{c}\text { Metode Pembinaan (X2) } \\
\text { dan Perilaku Keagamaan (y) }\end{array}$ & 0,197 & 0,444 & 0,405 & Tidak Signifikan \\
\hline $\begin{array}{c}\text { Materi Pembinaan (X3) dan } \\
\text { Perilaku Keagamaan (y) }\end{array}$ & 0,688 & 0,444 & 0,001 & Signifikan \\
\hline
\end{tabular}


Dari hasil analisis uji korelasi pada tabel di atas terlihat bahwa:

Korelasi Pembina Keagamaan (x1) dan Perilaku Keagamaan (y) memiliki nilai $r_{\text {hitung }}(0,101)<r_{\text {tabel }}(0,444)$ dan nilai signifikansi sebesar 0,671>0,05, berarti tidak ada hubungan yang signifikan antara variabel Pembina Keagamaan (x1) dan Perilaku Keagamaan (y). Korelasi Metode Pembinaan (x2) dan Perilaku Keagamaan (y) memiliki nilai $r_{\text {hitung }}(0,197)<r_{\text {tabel }}(0,444)$ dan nilai signifikansi sebesar $0,405>0,05$, berarti tidak ada hubungan yang signifikan antara variabel Metode Pembinaan (x1) dan Perilaku Keagamaan (y). Korelasi Materi Keagamaan (x3) dan Perilaku Keagamaan (y) memiliki nilai $r_{\text {hitung }}(0,688)>r_{\text {tabel }}(0,444)$ dan nilai signifikansi sebesar $0,001<0,05$, berarti ada hubungan yang signifikan antara variabel Materi Keagamaan (x3) dan Perilaku Keagamaan (y). Arah hubungannya adalah positif (nilai $r_{\text {hitung }}$ adalah positif). Artinya semakin baik Materi Keagamaan (x3) maka Perilaku Keagamaan (y) akan semakin baik pula.

Jadi dapat disimpulkan bahwa pengaruh yang signifikan terhadap perilaku keagamaan umat Buddha di wilayah Ampelgading adalah materi pembinaan keagamaan.

\section{Pengarub Pembinaan oleh Samanera dan Atthasilani terhadap Perilaku Keagamaan Umat Buddha di Dampit}

Hasil uji koefisien korelasi variabel bebas atau pengaruh pembinaan terhadap variabel terikat atau perilaku keagamaan umat Buddha di wilayah Dampit menggunakan SPSS 15.0 for windows adalah sebagai berikut.

\section{Tabel 3}

\section{Hasil Uii Koefisien Korelasi Variabel X dan Variabel Y}

\begin{tabular}{|ll|c|c|}
\multicolumn{1}{c}{ Correlations } \\
\hline & $\begin{array}{c}\text { Pembinaan } \\
(\mathrm{x})\end{array}$ & $\begin{array}{c}\text { Perilaku } \\
\text { Keagamaan } \\
(\mathrm{y})\end{array}$ \\
\hline Pembinaan $(\mathrm{x})$ & Pearson Correlation & 1 & $.852^{\star *}$ \\
& Sig. (2-tailed) & 20 & .000 \\
& $\mathrm{~N}$ & $.852^{\star *}$ & 1 \\
\hline Perilaku Keagamaan (y) & Pearson Correlation & .000 & 20 \\
& Sig. (2-tailed) & 20 & 20 \\
& $\mathrm{~N}$ & &
\end{tabular}

${ }^{* *}$. Correlation is significant at the 0.01 level (2-tailed). 
Dari tabel di atas dapat dilihat bahwa variabel pembinaan keagamaan (X) mempunyai pengaruh positif terhadap perilaku keagamaan di wilayah Dampit dengan nilai 0.852 atau $85,2 \%$ dan signifikan dengan nilai 0.008. Hal ini menunjukkan bahwa ada pengaruh yang signifikan antara variabel pembinaan keagamaan terhadap perilaku keagamaan umat Buddha di wilayah Dampit.

Selanjutnya dilakukan uji koefisien korelasi subvariabel untuk mengetahui subvariabel mana yang memberikan pengaruh terhadap perilaku keagamaan paling signifikan.

\section{Tabel 4}

\section{Rekapitulasi Hasil Analisis Korelasi Subvariabel}

\begin{tabular}{|c|c|c|c|c|}
\hline Variabel & $\mathrm{r}_{\text {hitung }}$ & $\mathrm{r}_{\text {tabel (n=20) }}$ & Sig. & Keterangan \\
\hline $\begin{array}{c}\text { Pembina Keagamaan (X1) } \\
\text { dan Perilaku Keagamaan (y) }\end{array}$ & 0,331 & 0,444 & 0,154 & Tidak Signifikan \\
\hline $\begin{array}{c}\text { Metode Pembinaan (X2) } \\
\text { dan Perilaku Keagamaan (y) }\end{array}$ & 0,694 & 0,444 & 0,001 & Signifikan \\
\hline $\begin{array}{c}\text { Materi Pembinaan (X3) dan } \\
\text { Perilaku Keagamaan (y) }\end{array}$ & 0,903 & 0,444 & 0,000 & Signifikan \\
\hline
\end{tabular}

Dari hasil analisis uji korelasi pada tabel di atas terlihat bahwa: Korelasi Pembina Keagamaan (x1) dan Perilaku Keagamaan (y) memiliki nilai $r_{\text {hitung }}(0,331)<r_{\text {tabel }}(0,444)$ dan nilai signifikansi sebesar 0,154>0,05, berarti tidak ada hubungan yang signifikan antara variabel Pembina Keagamaan (x1) dan Perilaku Keagamaan (y). Korelasi Metode Pembinaan (x2) dan Perilaku Keagamaan (y) memiliki nilai $r_{\text {hitung }}(0,694)>r_{\text {tabel }}(0,444)$ dan nilai signifikansi sebesar $0,001<0,05$, berarti ada hubungan yang signifikan antara variabel Metode Pembinaan (x1) dan Perilaku Keagamaan (y). Arah hubungannya adalah positif (nilai $r_{\text {hitung }}$ adalah positif). Artinya semakin baik Metode Pembinaan (x2) maka Perilaku Keagamaan (y)akan semakin baik pula. Korelasi Materi Keagamaan (x3) dan Perilaku Keagamaan (y) memiliki nilai $r_{\text {hitung }}(0,903)>r_{\text {tabel }}(0,444)$ dan nilai signifikansi sebesar $0,000<0,05$, berarti ada hubungan yang signifikan antara variabel Materi Keagamaan (x3) dan Perilaku Keagamaan (y). Arah hubungannya adalah positif (nilai $r_{\text {hitung }}$ adalah 
positif). Artinya semakin baik Materi Keagamaan (x3) maka Perilaku Keagamaan (y)akan semakin baik pula.

Jadi dapat disimpulkan bahwa pengaruh yang signifikan terhadap perilaku keagamaan umat Buddha di wilayah Dampit adalah metode pembinaan dan materi pembinaan keagamaan.

\section{Pengarub Pembinaan oleh Samanera dan Atthasilani terhadap} Perilaku Keagamaan Umat Buddha di Sumberpucung

Hasil uji koefisien korelasi variabel bebas atau pengaruh pembinaan terhadap variabel terikat atau perilaku keagamaan umat Buddha di wilayah Sumberpucung menggunakan SPSS 15.0 for windows adalah sebagai berikut.

\section{Tabel 5}

\section{Hasil Uji Koefisien Korelasi Variabel X dan Variabel Y}

\begin{tabular}{|c|c|c|c|}
\hline \multicolumn{4}{|c|}{ Correlations } \\
\hline & & $\begin{array}{c}\text { Pembinaan } \\
(\mathrm{x})\end{array}$ & $\begin{array}{c}\text { Perilaku } \\
\text { Keagamaan } \\
\text { (y) }\end{array}$ \\
\hline Pembinaan (x) & $\begin{array}{l}\text { Pearson Correlation } \\
\text { Sig. (2-tailed) } \\
\mathrm{N}\end{array}$ & $\begin{array}{r}1 \\
20 \\
\end{array}$ & $\begin{array}{c}.573^{\star *} \\
.008 \\
20 \\
\end{array}$ \\
\hline Perilaku Keagamaan (y) & $\begin{array}{l}\text { Pearson Correlation } \\
\text { Sig. (2-tailed) } \\
\mathrm{N}\end{array}$ & $\begin{array}{c}.573^{* *} \\
.008 \\
20\end{array}$ & $\begin{array}{r}1 \\
20\end{array}$ \\
\hline
\end{tabular}

${ }^{* *}$. Correlation is significant at the 0.01 level (2-tailed).

Dari tabel di atas dapat dilihat bahwa variabel pembinaan keagamaan (X) mempunyai pengaruh positif terhadap perilaku keagamaan di wilayah Sumberpucung dengan nilai 0.573 atau $57,3 \%$ dan signifikan dengan nilai 0.008. Hal ini menunjukkan bahwa ada pengaruh yang signifikan antara variabel pembinaan keagamaan terhadap perilaku keagamaan umat Buddha di wilayah Sumberpucung.

Selanjutnya dilakukan uji koefisien korelasi subvariabel untuk mengetahui subvariabel mana yang memberikan pengaruh terhadap perilaku keagamaan paling signifikan. 


\section{Tabel 6}

\section{Rekapitulasi Hasil Analisis Korelasi Subvariabel}

\begin{tabular}{|c|c|c|c|c|}
\hline Variabel & $\mathrm{r}_{\text {hitung }}$ & $\mathrm{r}_{\text {tabel }(\mathrm{n}=20)}$ & Sig. & Keterangan \\
\hline $\begin{array}{c}\text { Pembina Keagamaan } \\
\text { (X1) dan Perilaku } \\
\text { Keagamaan (y) }\end{array}$ & 0,101 & 0,444 & 0,671 & $\begin{array}{c}\text { Tidak } \\
\text { Signifikan }\end{array}$ \\
\hline $\begin{array}{c}\text { Metode Pembinaan } \\
\text { (X2) dan Perilaku } \\
\text { Keagamaan (y) }\end{array}$ & 0,197 & 0,444 & 0,405 & $\begin{array}{c}\text { Tidak } \\
\text { Signifikan }\end{array}$ \\
\hline $\begin{array}{c}\text { Materi Pembinaan } \\
\text { (X3) dan Perilaku } \\
\text { Keagamaan (y) }\end{array}$ & 0,688 & 0,444 & 0,001 & Signifikan \\
\hline
\end{tabular}

Dari hasil analisis uji korelasi pada tabel di atas terlihat bahwa: Korelasi Pembina Keagamaan (x1) dan Perilaku Keagamaan (y) memiliki nilai $r_{\text {hitung }}(0,101)<r_{\text {tabel }}(0,444)$ dan nilai signifikansi sebesar 0,671>0,05, berarti tidak ada hubungan yang signifikan antara variabel Pembina Keagamaan (x1) dan Perilaku Keagamaan (y). Korelasi Metode Pembinaan (x2) dan Perilaku Keagamaan (y) memiliki nilai $r_{\text {hitung }}(0,197)<r_{\text {tabel }}(0,444)$ dan nilai signifikansi sebesar $0,405>0,05$, berarti tidak ada hubungan yang signifikan antara variabel Metode Pembinaan (x1) dan Perilaku Keagamaan (y). Korelasi Materi Keagamaan (x3) dan Perilaku Keagamaan (y) memiliki nilai $r_{\text {hitung }}(0,688)>r_{\text {tabel }}(0,444)$ dan nilai signifikansi sebesar $0,001<0,05$, berarti ada hubungan yang signifikan antara variabel Materi Keagamaan (x3) dan Perilaku Keagamaan (y). Arah hubungannya adalah positif (nilai $r_{\text {hitung }}$ adalah positif). Artinya semakin baik Materi Keagamaan (x3) maka Perilaku Keagamaan (y) akan semakin baik pula.

Jadi dapat disimpulkan bahwa pengaruh yang signifikan terhadap perilaku keagamaan umat Buddha di wilayah Sumberpucung adalah materi pembinaan keagamaan. 
Pengarub Pembinaan oleb Samanera dan Atthasilani terhadap Perilaku Keagamaan Umat Buddha di Pait

Hasil uji koefisien korelasi variabel bebas atau pengaruh pembinaan terhadap variabel terikat atau perilaku keagamaan umat Buddha di wilayah Sumberpucung menggunakan SPSS 15.0 for windows adalah sebagai berikut.

\section{Tabel 7}

\section{Hasil Uji Koefisien Korelasi Variabel X dan Variabel Y}

\section{Correlations}

\begin{tabular}{|ll|c|c|}
\hline & & $\begin{array}{c}\text { Pembinaan } \\
(\mathrm{x})\end{array}$ & $\begin{array}{c}\text { Perilaku } \\
\text { Keagamaan } \\
(\mathrm{y})\end{array}$ \\
\hline Pembinaan $(\mathrm{x})$ & Pearson Correlation & 1 & $.733^{\star *}$ \\
& Sig. (2-tailed) & 40 & .000 \\
& $\mathrm{~N}$ & $.733^{* *}$ & 40 \\
\hline Perilaku Keagamaan (y) & Pearson Correlation & .000 & 1 \\
& Sig. (2-tailed) & 40 & 40 \\
& $\mathrm{~N}$ & 40 & \\
\end{tabular}

${ }^{* *}$. Correlation is significant at the 0.01 level (2-tailed).

Dari tabel di atas dapat dilihat bahwa variabel pembinaan keagamaan (X) mempunyai pengaruh positif terhadap perilaku keagamaan di wilayah Pait dengan nilai 0.773 atau $77,3 \%$ dan signifikan dengan nilai 0,000. Hal ini menunjukkan bahwa ada pengaruh yang signifikan antara variabel pembinaan keagamaan terhadap perilaku keagamaan umat Buddha di wilayah Pait.

Selanjutnya dilakukan uji koefisien korelasi subvariabel untuk mengetahui subvariabel mana yang memberikan pengaruh terhadap perilaku keagamaan paling signifikan. 


\section{Tabel 8}

\section{Rekapitulasi Hasil Analisis Korelasi Subvariabel}

\begin{tabular}{|c|c|c|c|c|}
\hline Variabel & $\mathrm{r}_{\text {hitung }}$ & $\mathrm{r}_{\text {tabel }(\mathrm{n}=40)}$ & Sig. & Keterangan \\
\hline $\begin{array}{c}\text { Pembina Keagamaan (X1) } \\
\text { dan Perilaku Keagamaan (y) }\end{array}$ & 0,627 & 0,312 & 0,000 & Signifikan \\
\hline $\begin{array}{c}\text { Metode Pembinaan (X2) } \\
\text { dan Perilaku Keagamaan (y) }\end{array}$ & 0,627 & 0,312 & 0,000 & Signifikan \\
\hline $\begin{array}{c}\text { Materi Pembinaan (X3) dan } \\
\text { Perilaku Keagamaan (y) }\end{array}$ & 0,689 & 0,312 & 0,000 & Signifikan \\
\hline
\end{tabular}

Dari hasil analisis uji korelasi pada tabel di atas terlihat bahwa: Korelasi Pembina Keagamaan (x1) dan Perilaku Keagamaan (y) memiliki nilai $r_{\text {hitung }}(0,627)>r_{\text {tabel }}(0,312)$ dan nilai signifikansi sebesar $0,000<0,05$, berarti ada hubungan yang signifikan antara variabel Pembina Keagamaan (x1) dan Perilaku Keagamaan (y). Arah hubungannya adalah positif (nilai $r_{\text {hitung }}$ adalah positif). Artinya semakin baik Pembina Keagamaan (x1) maka Perilaku Keagamaan (y) akan semakin baik pula. Korelasi Metode Pembinaan (x2) dan Perilaku Keagamaan (y) memiliki nilai $r_{\text {hitung }}(0,627)>r_{\text {tabel }}(0,312)$ dan nilai signifikansi sebesar $0,000<0,05$, berarti ada hubungan yang signifikan antara variabel Metode Pembinaan (x1) dan Perilaku Keagamaan (y). Arah hubungannya adalah positif (nilai $r_{\text {hitung }}$ adalah positif). Artinya semakin baik Metode Pembinaan (x2) maka Perilaku Keagamaan (y)akan semakin baik pula. Korelasi Materi Keagamaan (x3) dan Perilaku Keagamaan (y) memiliki nilai $r_{\text {hitung }}(0,689)$ $>r_{\text {tabel }}(0,312)$ dan nilai signifikansi sebesar $0,000<0,05$, berarti ada hubungan yang signifikan antara variabel Materi Keagamaan (x3) dan Perilaku Keagamaan (y). Arah hubungannya adalah positif (nilai $r_{\text {hitung }}$ adalah positif). Artinya semakin baik Materi Keagamaan (x3) maka Perilaku Keagamaan (y)akan semakin baik pula.

Jadi dapat disimpulkan bahwa pengaruh yang signifikan terhadap perilaku keagamaan umat Buddha di wilayah Pait adalah pembina keagamaan, metode pembinaan, dan materi pembinaan. 
Pengarub Pembinaan oleh Samanera dan Atthasilani terhadap Perilaku Keagamaan Umat Buddha di Ngandat

Hasil uji koefisien korelasi variabel bebas atau pengaruh pembinaan terhadap variabel terikat atau perilaku keagamaan umat Buddha di wilayah Ngandat menggunakan SPSS 15.0 for windows adalah sebagai berikut.

\section{Tabel 9}

\section{Hasil Uji Koefisien Korelasi Variabel X dan Variabel Y}

\section{Correlations}

\begin{tabular}{|ll|c|c|}
\hline & & $\begin{array}{c}\text { Pembinaan } \\
(\mathrm{x})\end{array}$ & $\begin{array}{c}\text { Perilaku } \\
\text { Keagamaan } \\
(\mathrm{y})\end{array}$ \\
\hline Pembinaan $(\mathrm{x})$ & Pearson Correlation & 1 & $.763^{\star *}$ \\
& Sig. (2-tailed) & & .000 \\
& $\mathrm{~N}$ & 20 & 20 \\
\hline Perilaku Keagamaan (y) & Pearson Correlation & $.763^{* *}$ & 1 \\
& Sig. (2-tailed) & .000 & \\
& $\mathrm{~N}$ & 20 & 20 \\
\hline
\end{tabular}

${ }^{* *}$. Correlation is significant at the 0.01 level (2-tailed).

Dari tabel di atas dapat dilihat bahwa variabel pembinaan keagamaan (X) mempunyai pengaruh positif terhadap perilaku keagamaan di wilayah Dusun Ngandat dengan nilai 0.763 atau $76,3 \%$ dan signifikan dengan nilai 0,000. Hal ini menunjukkan bahwa ada pengaruh yang signifikan antara variabel pembinaan keagamaan terhadap perilaku keagamaan Umat Buddha di wilayah Dusun Ngandat.

Selanjutnya dilakukan uji koefisien korelasi subvariabel untuk mengetahui subvariabel mana yang memberikan pengaruh terhadap perilaku keagamaan paling signifikan. 
Tabel 10

Rekapitulasi Hasil Analisis Korelasi Subvariabel

\begin{tabular}{|c|c|c|c|c|}
\hline Variabel & $\mathrm{r}_{\text {hitung }}$ & $\mathrm{r}_{\text {tabel }(\mathrm{n}=20)}$ & Sig. & Keterangan \\
\hline $\begin{array}{c}\text { Pembina Keagamaan } \\
\text { (X1) dan Perilaku } \\
\text { Keagamaan (y) }\end{array}$ & 0,303 & 0,444 & 0,195 & Tidak Signifikan \\
\hline $\begin{array}{c}\text { Metode Pembinaan } \\
\text { (X2) dan Perilaku } \\
\text { Keagamaan (y) }\end{array}$ & 0,677 & 0,444 & 0,001 & Tidak Signifikan \\
\hline $\begin{array}{c}\text { Materi Pembinaan } \\
\text { (X3) dan Perilaku } \\
\text { Keagamaan (y) }\end{array}$ & 0,810 & 0,444 & 0,000 & Signifikan \\
\hline
\end{tabular}

Dari hasil analisis uji korelasi pada tabel di atas terlihat bahwa: Korelasi Pembina Keagamaan (x1) dan Perilaku Keagamaan (y) memiliki nilai $r_{\text {hitung }}(0,303)<r_{\text {tabel }}(0,444)$ dan nilai signifikansi sebesar 0,195>0,05, berarti tidak ada hubungan yang signifikan antara variabel Pembina Keagamaan (x1) dan Perilaku Keagamaan (y). Korelasi Metode Pembinaan (x2) dan Perilaku Keagamaan (y) memiliki nilai $r_{\text {hitung }}(0,677)>r_{\text {tabel }}(0,444)$ dan nilai signifikansi sebesar $0,001<0,05$, berarti ada hubungan yang signifikan antara variabel Metode Pembinaan (x1) dan Perilaku Keagamaan (y). Arah hubungannya adalah positif (nilai $r_{\text {hitung }}$ adalah positif). Artinya semakin baik Metode Pembinaan (x2) maka Perilaku Keagamaan (y)akan semakin baik pula. Korelasi Materi Keagamaan (x3) dan Perilaku Keagamaan (y) memiliki nilai $r_{\text {hitung }}(0,810)>r_{\text {tabel }}(0,444)$ dan nilai signifikansi sebesar $0,000<0,05$, berarti ada hubungan yang signifikan antara variabel Materi Keagamaan (x3) dan Perilaku Keagamaan (y). Arah hubungannya adalah positif (nilai $r_{\text {hitung }}$ adalah positif). Artinya semakin baik Materi Keagamaan (x3) maka Perilaku Keagamaan (y)akan semakin baik pula.

Jadi dapat disimpulkan bahwa pengaruh yang signifikan terhadap perilaku keagamaan umat Buddha di wilayah Ngandat adalah materi pembinaan keagamaan. 
Pengarub Pembinaan oleh Samanera dan Atthasilani terhadap Perilaku Keagamaan Umat Buddha di Kota Malang

Hasil uji koefisien korelasi variabel bebas atau pengaruh pembinaan terhadap variabel terikat atau perilaku keagamaan umat Buddha di wilayah Kota Malang menggunakan SPSS 15.0 for windows adalah sebagai berikut.

\section{Tabel 11}

Hasil Uji Koefisien Korelasi Variabel X dan Variabel Y

\section{Correlations}

\begin{tabular}{|ll|r|r|}
\hline & Pembinaan \\
$(\mathrm{x})$ & $\begin{array}{c}\text { Perilaku } \\
\text { Keagamaan } \\
(\mathrm{y})\end{array}$ \\
\hline Pembinaan $(\mathrm{x})$ & Pearson Correlation & 1 & $.513^{* *}$ \\
& Sig. (2-tailed) & 30 & .004 \\
& $\mathrm{~N}$ & $.513^{* *}$ & 30 \\
\hline Perilaku Keagamaan (y) & Pearson Correlation & .004 & 1 \\
& Sig. (2-tailed) & 30 & 30 \\
& $\mathrm{~N}$ & & \\
\hline
\end{tabular}

${ }^{* *}$. Correlation is significant at the 0.01 level (2-tailed).

Dari tabel di atas dapat dilihat bahwa variabel pembinaan keagamaan (X) mempunyai pengaruh positif terhadap perilaku keagamaan di wilayah Kota Malang dengan nilai 0.513 atau 51,3\% dan signifikan dengan nilai 0,004. Hal ini menunjukkan bahwa ada pengaruh yang signifikan antara variabel pembinaan keagamaan terhadap perilaku keagamaan Umat Buddha di wilayah Kota Malang.

Selanjutnya dilakukan uji koefisien korelasi subvariabel untuk mengetahui subvariabel mana yang memberikan pengaruh terhadap perilaku keagamaan paling signifikan. 
Tabel 12

Rekapitulasi Hasil Analisis Korelasi Subvariabel

\begin{tabular}{|c|c|c|c|c|}
\hline Variabel & $\mathrm{r}_{\text {hitung }}$ & $\mathrm{r}_{\text {tabel }(\mathrm{n}=30)}$ & Sig. & Keterangan \\
\hline $\begin{array}{c}\text { Pembina Keagamaan } \\
\text { (X1) dan Perilaku } \\
\text { Keagamaan (y) }\end{array}$ & 0,334 & 0,361 & 0,071 & $\begin{array}{c}\text { Tidak } \\
\text { Signifikan }\end{array}$ \\
\hline $\begin{array}{c}\text { Metode Pembinaan } \\
\text { (X2) dan Perilaku } \\
\text { Keagamaan (y) }\end{array}$ & 0,477 & 0,361 & 0,008 & Signifikan \\
\hline $\begin{array}{c}\text { Materi Pembinaan } \\
\text { (X3) dan Perilaku } \\
\text { Keagamaan (y) }\end{array}$ & 0,527 & 0,361 & 0,003 & Signifikan \\
\hline
\end{tabular}

Dari hasil analisis uji korelasi pada tabel di atas terlihat bahwa: Korelasi Pembina Keagamaan (x1) dan Perilaku Keagamaan (y) memiliki nilai $r_{\text {hitung }}(0,334)<r_{\text {tabel }}(0,361)$ dan nilai signifikansi sebesar 0,071>0,05, berarti tidak ada hubungan yang signifikan antara variabel Pembina Keagamaan (x1) dan Perilaku Keagamaan (y). Korelasi Metode Pembinaan (x2) dan Perilaku Keagamaan (y) memiliki nilai $r_{\text {hitung }}(0,477)>r_{\text {tabel }}(0,361)$ dan nilai signifikansi sebesar $0,008<0,05$, berarti ada hubungan yang signifikan antara variabel Metode Pembinaan (x1) dan Perilaku Keagamaan (y). Arah hubungannya adalah positif (nilai $r_{\text {hitung }}$ adalah positif). Artinya semakin baik Metode Pembinaan (x2) maka Perilaku Keagamaan (y)akan semakin baik pula. Korelasi Materi Keagamaan (x3) dan Perilaku Keagamaan (y) memiliki nilai $r_{\text {hitung }}(0,527)>r_{\text {tabel }}(0,361)$ dan nilai signifikansi sebesar $0,003<0,05$, berarti ada hubungan yang signifikan antara variabel Materi Keagamaan (x3) dan Perilaku Keagamaan (y). Arah hubungannya adalah positif (nilai $r_{\text {hitung }}$ adalah positif). Artinya semakin baik Materi Keagamaan (x3) maka Perilaku Keagamaan (y) akan semakin baik pula.

Jadi dapat disimpulkan bahwa pengaruh yang signifikan terhadap perilaku keagamaan umat Buddha di wilayah Kota Malang adalah metode pembinaan dan materi pembinaan keagamaan. 
Pengarub Pembinaan oleh Samanera dan Atthasilani terhadap Perilaku Keagamaan Umat Buddha di Malang Raya

Hasil uji koefisien korelasi variabel bebas atau pengaruh pembinaan terhadap variabel terikat atau perilaku keagamaan umat Buddha di wilayah Malang Raya menggunakan SPSS 15.0 for windows adalah sebagai berikut.

\section{Tabel 13}

Hasil Uji Koefisien Korelasi Variabel X dan Variabel Y

\section{Correlations}

\begin{tabular}{|ll|r|r|}
\hline & & $\begin{array}{c}\text { Pembinaan } \\
(\mathrm{x})\end{array}$ & $\begin{array}{c}\text { Perilaku } \\
\text { Keagamaan } \\
(\mathrm{y})\end{array}$ \\
\hline Pembinaan $(\mathrm{x})$ & Pearson Correlation & 1 & $.724^{\text {** }}$ \\
& Sig. (2-tailed) & 150 & .000 \\
& $\mathrm{~N}$ & $.724^{* *}$ & 150 \\
\hline Perilaku Keagamaan (y) & Pearson Correlation & .000 & 1 \\
& Sig. (2-tailed) & 150 & 150 \\
& $\mathrm{~N}$ & & \\
\hline
\end{tabular}

${ }^{* *}$. Correlation is significant at the 0.01 level (2-tailed).

Dari tabel di atas dapat dilihat bahwa variabel pembinaan keagamaan (X) mempunyai pengaruh positif terhadap perilaku keagamaan di wilayah Malang Raya dengan nilai 0.724 atau $72,4 \%$ dan signifikan dengan nilai 0.000. Hal ini menunjukkan bahwa ada pengaruh yang signifikan antara variabel pembinaan keagamaan terhadap perilaku keagamaan umat Buddha di wilayah Malang Raya.

Selanjutnya dilakukan uji koefisien korelasi subvariabel untuk mengetahui subvariabel mana yang memberikan pengaruh terhadap perilaku keagamaan paling signifikan. 


\section{Tabel 14}

\section{Rekapitulasi Hasil Analisis Korelasi Subvariabel}

\begin{tabular}{|c|c|c|c|c|}
\hline Variabel & $r_{\text {hitung }}$ & $r_{\text {tabel }(\mathrm{n}=150)}$ & Sig. & Keterangan \\
\hline $\begin{array}{c}\text { Pembina Keagamaan } \\
\text { (X1) dan Perilaku } \\
\text { Keagamaan (y) }\end{array}$ & 0,474 & 0,160 & 0,000 & Signifikan \\
\hline $\begin{array}{c}\text { Metode Pembinaan } \\
\text { (X2) dan Perilaku } \\
\text { Keagamaan (y) }\end{array}$ & 0,544 & 0,160 & 0,000 & Signifikan \\
\hline $\begin{array}{c}\text { Materi Pembinaan } \\
\text { (X3) dan Perilaku } \\
\text { Keagamaan (y) }\end{array}$ & 0,756 & 0,160 & 0,000 & Signifikan \\
\hline
\end{tabular}

Dari hasil analisis uji korelasi pada tabel di atas terlihat bahwa: Korelasi Pembina Keagamaan (x1) dan Perilaku Keagamaan (y) memiliki nilai $r_{\text {hitung }}(0,474)>r_{\text {tabel }}(0,160)$ dan nilai signifikansi sebesar $0,000<0,05$, berarti ada hubungan yang signifikan antara variabel Pembina Keagamaan (x1) dan Perilaku Keagamaan (y). Arah hubungannya adalah positif (nilai $r_{\text {hitung }}$ adalah positif). Artinya semakin baik Pembina Keagamaan (x1) maka Perilaku Keagamaan (y)akan semakin baik pula. Korelasi Metode Pembinaan (x2) dan Perilaku Keagamaan (y) memiliki nilai $r_{\text {hitung }}(0,544)>r_{\text {tabel }}(0,160)$ dan nilai signifikansi sebesar $0,000<0,05$, berarti ada hubungan yang signifikan antara variabel Metode Pembinaan (x1) dan Perilaku Keagamaan (y). Arah hubungannya adalah positif (nilai $r_{\text {hitung }}$ adalah positif). Artinya semakin baik Metode Pembinaan (x2) maka Perilaku Keagamaan (y)akan semakin baik pula. Korelasi Materi Keagamaan (x3) dan Perilaku Keagamaan (y) memiliki nilai $r_{\text {hitung }}(0,756)$ $>r_{\text {tabel }}(0,160)$ dan nilai signifikansi sebesar $0,000<0,05$, berarti ada hubungan yang signifikan antara variabel Materi Keagamaan (x3) dan Perilaku Keagamaan (y). Arah hubungannya adalah positif (nilai $r_{\text {hitung }}$ adalah positif). Artinya semakin baik Materi Keagamaan (x3) maka Perilaku Keagamaan (y)akan semakin baik pula.

Jadi dapat disimpulkan bahwa pengaruh yang signifikan terhadap perilaku keagamaan umat Buddha di wilayah Malang Raya adalah pembina keagamaan, metode pembinaan, dan materi pembinaan keagamaan. 


\section{Kesimpulan}

Berdasarkan hasil penelitian yang dilakukan terhadap kegiatan pembinaan keagamaan di wilayah Malang Raya diperoleh kesimpulan bahwa pembinaan keagamaan memiliki pengaruh yang signifikan terhadap perilaku keagamaan umat Buddha di wilayah Malang Raya. Hal ini dapat dibuktikan dari nilai korelasi 0,724 atau $72,4 \%$ dan signifikan dengan nilai 0,000. Hal ini menunjukkan bahwa ada pengaruh yang signifikan antara variabel pembinaan keagamaan terhadap perilaku keagamaan umat Buddha di wilayah Malang Raya.

\section{Daftar Pustaka}

Anshari, Endang Syaifudin. 1980. Pendidikan Anak dalam Islam. Jakarta: Pustaka Amani.

Bodhi, Bhikkhu. 2005. In the Buddha's Words. Boston Wisdom Publication.

BPPD Kabupaten Malang. 2016. Statistik Pembangunan Daerah Kabupaten Malang Tahun 2015. BPPD Kab Malang.

BPS Kota Malang. 2011. Malang dalam Angka 2011. BPS Kota Malang.

Jotalankara. 2004. Ajaran-ajaran Dasar Buddhisme. Terjemahan Jani Tandi Wiharja. 2013. Jakarta: Yayasan PJBI.

Notoatmodjo, Soekidjo. 2010. Ilmu Perilaku Kesehatan. Jakarta : Rineka Cipta.

Purwoto, dkk. 2016. Pola Konversi Agama Masyarakat Buddhis ke Non-Buddhis (Study Kasus di Kabupaten Malang). Prosiding Penelitian Dosen PTKB Tahun 2016. Jakarta: Direktorat Jenderal Bimas Buddha Kemenag RI.

Prasetyo, Bambang dan Lina Miftahul. 2005. Metode Penelitian Kuantitaitf: Teori dan Aplikasi. Jakarta: Raja Grafindo Persada.

Sarada, Ven. Weragoda. 1993. Treasury of Truth The Illustrated Dhammapada. Taipei: The Corporate Body of the Buddha Educational Foundation

Slavin, Robert. 2011. Psikologi Pendidikan:Teori dan Praktik. Jakarta: Indeks.

Syafaat, dkk. 2008. Perilaku Manusia (Teori dan Pengukurannya). Pustaka Pelajar. 